Annals of Warsaw University of Life Sciences - SGGW

Land Reclamation No 42 (1), 2010: 177-185

(Ann. Warsaw Univ. of Life Sci. - SGGW, Land Reclam. 42 (1), 2010)

\title{
Sediment segregation on weirs of lowland rivers
}

\author{
SŁAWOMIR BAJKOWSKI \\ Department Hydraulic Engineering and Environmental Restoration, Warsaw University of Life \\ Sciences - SGGW
}

\begin{abstract}
Sediment segregation on weirs of lowland rivers. Erosion and accumulation processes in the vicinity of water structures develop depending on the life of the facility, hydrological regime and morphology of the riverbed. Diversification of flow characteristics affects the segregation of bed sediment on section of period of weirs. Knowledge of factors determining granulometric diversity of bottom material allows for more appropriate bed and riverbanks protections design. It also enables estimation of the conditions of sediment transport down the watercourse and its participation in the balance of the transport of bottom material in the watercourse. Areas where sediment accumulates on the water structures are up water and down water positions, stilling basin and other cavities of the structure. The article presents an analysis of granulometric composition of bottom material in selected lowland weirs. Research facilities are weirs located on lowland rivers. Segregation of sediment material was observed on weir sections. Thickest sediment is piled in up water, smallest in down water.
\end{abstract}

Key words: weir, sediment, erosion, deposition.

\section{INTRODUCTION}

Discontinuities of cross sections and bottom slope occur in stream troughs. These affect the depth of water at damming section and shape the water flow speed. Variable hydraulic conditions result in accumulation of bed load in the zones of quiet water movement and erosion phenomenon within the zones of high-speed water flow. Water structures modify the hydrological regime of rivers and the diversity of streams' hydraulic parameters, opposite to not built-up watercourses. In the upper weir part a significant increase in the depth of water occurs. However, in the lower weir part, below the overflows, it clearly diminishes. These effects are accompanied by opposite trends in flow velocity - above the structure the speed decreases, below it increases. Various parameters of water flow within the damming section cause changes in sediment flow conditions [Zawadzki, Hämmerling 2008]. The accumulated bed material influences the flow conditions, limits the capacity of damming equipment and impedes their use.

Dimensioning of objects, so that they secure continuity of the stream's hydraulic parameters, is the most important difficulty faced by designers of water structures. Changes in the regime of sediment movement in the sector of water structures result mainly from the presence of lower structures, such as thresholds, as well as lateral - wing-wall abutments. These structures disturb the water flow, causing changes in hydraulic parame- 
ters that determine transport capacity of the stream [Dąbkowski, Skibiński, Żbikowski 1982]. Watercourse obstacles modify the forms of flow and disturb the settled sediment transport regime. These obstacles include discontinuity of longitudinal bottom slope, changes of shape and dimensions of the cross section, as well as water structures. The areas in which sediment can accumulate in water structures are: upper weir part, cavities of structure and lower weir part. Protection of rear apron of the bottom at sill limits erosion processes in trough [Breusers, Raudkivi 1991]. Sediment layers impede the movement of pollutants, conservation of barrage and maintenance of even bottom grade line slope. The river bed decline in the stilling basin increases sedimentation process. There is strong possibility that bed load material accumulate in this section.

Water flow parameters on damming objects with movable gates are shaped by their design and operational requirements. The process of accumulation in the upper and lower weir parts evolve according to the lifetime of object. In this process there are three phases distinguished [Lappo et al. 1988]:

Phase I - the initial period of the process development with increased erosion in the lower weir bay and bed material accumulation in the upper weir bay.

Phase II - the transitional period, in which the movement of sediment accumulated in the upper weir part and its transport down the watercourse begin.

Phase III - the period of constant sediment transport through the damming section from the upper to the lower weir area, during which the accumula- tion of bed material load may occur in the lower weir area.

The duration of Phase I depends on the density of river bed material, the quantity sediment load and the parameters of the fold forming above the object. The end of Phase I is the moment when the front of the fold reaches the damming section and bed material begins to flow into the tail weir part. River bed material accumulated in the upper weir part causes an increase of water level. The value of the largest increase of water level at the place of backwater disappearance is projected according to the bottom slope and the concentration of sediment in the stream. The development and duration of Phase II depend on the volatility of flows, the amount of load bed material accumulated over the structure, the sill crest elevation, as well as the form and extent of scouring below weir. In Phase III the accumulation of sediment below the structure appears which is accompanied by the increase of tail water level. Silting of the tail water in the segment of stream trough changes appears when the amount of particles bed load and suspended load in water is larger than transport capacity of the stream.

The research discussed in the article concerns the assessment of granulometric parameters of the bed material in damming section. Bed sediment samples were collected from the high water (upper weir part) and tail water (lower weir part) sections. They were analysed in order to determine the degree of sediment sorting on weirs. Defined characteristics calculated for the samples were used to assess the diversity of material drawn from various sections. Obtained parameters were used to assess the 
degree of bed load sorting in analysed damming sections of rivers. The analysis was conducted to determine constructional parameters of structures that may affect the stream's transport continuity. The study was funded from research resources in 2008-2011.

\section{MATERIAL}

The analysed weirs are situated on lowland rivers with bed alluvial. The processes of sediment segregation on weirs were estimated by analysing constructional parameters of structures determining maintenance of slope within the structure itself, hydraulic conditions and the characteristics of bed sediment. The list of examined weirs and their basic parameters are presented in Table 1. The general scheme of the weir is shown in Figure 1.

The examined objects are weirs without upper thresholds, with the overflow situated on the elevation of the river bed. On the body of weirs there are movable gates located. The devices used for dissipation of energy in all weirs are stilling basins. On the Jazgarzew and Transbór weirs flat flap gates are used and on the Kocewo weir - double plain gates. In the upper and lower weir parts there are river bed protection and bank lining. The bottom line in the structure's section reverses at the entrance to the basin, as well as at the exit from the basin to the lower weir part. In the analysis the slope of construction's bottom is presented, calculated between the sill crest and the

TABLE 1. Weirs characteristics

\begin{tabular}{|c|l|l|l|l|c|c|c|c|c|c|c|c|}
\hline No & Weir & River & Gates & $n$ & $\begin{array}{c}b \\
{[\mathrm{~m}]}\end{array}$ & $\begin{array}{c}B \\
{[\mathrm{~m}]}\end{array}$ & $\begin{array}{c}d_{\mathrm{n}} \\
{[\mathrm{m}]}\end{array}$ & $\begin{array}{c}p_{\mathrm{d}} \\
{[\mathrm{m}]}\end{array}$ & $\begin{array}{c}L_{\mathrm{p}} \\
{[\mathrm{m}]}\end{array}$ & $\begin{array}{c}L_{\mathrm{n}} \\
{[\mathrm{m}]}\end{array}$ & $\begin{array}{c}L_{\mathrm{w}} \\
{[\mathrm{m}]}\end{array}$ & $\begin{array}{c}J_{\mathrm{d}} \\
{[\%]}\end{array}$ \\
\hline 1 & Jazgarzew & Jeziorka & $\mathrm{KP}^{1)}$ & 3 & 3.0 & 9.0 & 0.50 & 1.30 & 1.90 & 13.60 & 0.50 & 9.6 \\
\hline 2 & Transbór & Świder & $\mathrm{KC}^{2)}$ & 2 & 3.0 & 6.0 & 0.30 & 0.46 & 1.95 & 7.45 & 0.30 & 6.2 \\
\hline 3 & Kocewo & Wkra & $\mathrm{ZD}^{3)}$ & 2 & 4.0 & 8.0 & 0.30 & 0.15 & 2.25 & 7.45 & 0.30 & 2.0 \\
\hline
\end{tabular}

${ }^{1)} \mathrm{KP}$ - flat flap gates, ${ }^{2} \mathrm{KC}$ - cylindrical flap gates, ${ }^{3)} \mathrm{ZD}$ - double plain gates.

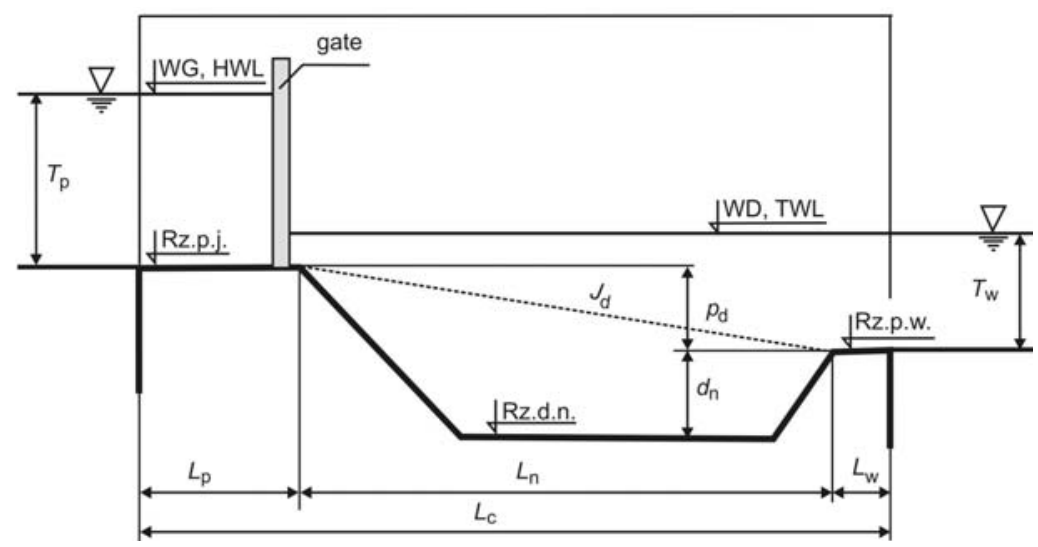

FIGURE 1. Weirs parameters 
TABLE 2. Sediment characteristics

\begin{tabular}{|c|c|c|c|c|c|c|}
\hline \multirow{2}{*}{$\begin{array}{l}\text { Collecting } \\
\text { place }\end{array}$} & \multicolumn{2}{|c|}{$\begin{array}{l}\text { Jazgarzew } \\
\text { Weir parts }\end{array}$} & \multicolumn{2}{|c|}{$\begin{array}{c}\text { Transbór } \\
\text { Weir parts }\end{array}$} & \multicolumn{2}{|c|}{$\begin{array}{c}\text { Kocewo } \\
\text { Weir parts }\end{array}$} \\
\hline & upper & lower & upper & lower & upper & lower \\
\hline Kind of soils & $\mathrm{Pd}$ & Ps & Ps & Ps & Ps & Ps \\
\hline$D_{50}[\mathrm{~mm}]$ & 0.151 & 0.367 & 0.435 & 0.340 & 0.422 & 0.412 \\
\hline$D_{\mathrm{p}}[\mathrm{mm}]$ & 0.369 & 0.405 & 0.532 & 0.372 & 0.521 & 0.484 \\
\hline$\rho_{\mathrm{s}}\left[\mathrm{g} \mathrm{cm}^{-3}\right]$ & 2.67 & 2.65 & 2.59 & 2.59 & 2.61 & 2.63 \\
\hline \multirow[t]{2}{*}{$C_{\mathrm{d}}$} & 1.274 & 0.659 & 0.899 & 0.938 & 1.255 & 1.097 \\
\hline & $\begin{array}{c}\text { dominate } \\
\text { particle } \\
>D_{50}\end{array}$ & $\begin{array}{c}\text { dominate } \\
\text { particle } \\
<D_{50}\end{array}$ & $\begin{array}{l}\text { dominate } \\
\text { particle } \\
<D_{50}\end{array}$ & $\begin{array}{l}\text { dominate } \\
\text { particle } \\
<D_{50}\end{array}$ & $\begin{array}{c}\text { dominate } \\
\text { particle } \\
>D_{50}\end{array}$ & $\begin{array}{c}\text { dominate } \\
\text { particle } \\
>D_{50}\end{array}$ \\
\hline \multirow{2}{*}{$\begin{array}{l}G S O^{1)} \\
\text { Sorting }\end{array}$} & 0.94 & 0.92 & 0.85 & 0.66 & 0.59 & 0.62 \\
\hline & \multicolumn{2}{|c|}{ moderately } & moderately & moderately well & \multicolumn{2}{|c|}{ moderately well } \\
\hline \multirow{2}{*}{$\begin{array}{l}G S K^{2)} \\
\text { Skewness }\end{array}$} & -0.23 & 0.24 & 0.03 & 0.09 & -0.22 & -0.08 \\
\hline & negative & positive & symmetrical & symmetrical & negative & symmetrical \\
\hline \multirow{2}{*}{$\begin{array}{l}G S P^{3)} \\
\text { Kurtosis }\end{array}$} & 1.40 & 1.33 & 1.32 & 1.14 & 1.02 & 1.11 \\
\hline & leptokurtic & leptokurtic & leptokurtic & leptokurtic & normals & normals \\
\hline
\end{tabular}

$G S O^{1)}$ - standard deviation, $G S K^{2)}$ - skewness, $G S P^{3)}$ - kurtosis.

bottom of the lower weir part, regardless of the shape and dimensions of the stilling basin.

The bed material samples were collected from the upper weir cross section and the sediment accumulated below the energy dissipation devices. Basic characteristics of the sediment are presented in Table 2. In the stream trough above and below the Transbor and Kocewo weirs the medium sand appears. Only at the Jagarzewo weir in the upper weir part the sand is fine, and in the lower - medium. Taking into account only the type of bed material, it can be concluded that the sorting of sand in the examined weirs is insubstantial. It is indicated by variety of geometrical parameters of bed material particles within limited range of diameters.

\section{METHODS}

Sediment transport through water structures depends on structural parameters of the object, water flow's hydraulic conditions and characteristics of transported material. The constructional parameters of the weir which influence sediment transport the most are:

- The number of openings and the width of weir utilised by water.

- The width of river and its ratio to the length of weir openings.

- The shape, particularly height, of sill $-p_{\mathrm{g}}$.

- The type and height of gates maintaining damming.

- The type of equipment dissipating energy, for stilling basins - their depth $d_{\mathrm{n}}$ and length $L_{\mathrm{n}}$.

- The lower sill height $p_{\mathrm{d}}$.

- The total length of weir structure $L_{\mathrm{c}}$.

- The type and length of lower weir part's protection.

- The longitudinal slope of structure $J_{\mathrm{d}}$.

Hydraulic parameters include:

- Flow rate.

- High water depth. 
- Tail water depth.

- Backwater height.

Sediment's granulometric characteristics are as follows:

- Median grain size $D_{50}$.

- Mean-weighted size of particles $D_{\mathrm{p}}$.

- Domination coefficient $C_{\mathrm{d}}$.

- Standard deviation GSO.

- Skewness GSK.

- Kurtosis GSP.

\section{RESULTS}

In the upper weir part of the Jazgarzew weir the sediment accumulated is finer than in the river below (Fig. 2a). The bed material is characterized by moderate sorting, which means relatively small particles' diameter variation. It is also expressed by the leptokurtic nature of grain hydrograph. Particles larger than $D_{50}$ dominate above the weir, below - they are smaller than $D_{50}$. This weir has the largest plate's longitudinal slope of $9.6 \%$ and the sand is characterized by the highest density (Tab. 1). Above the Transbór weir the sand is fatter and below it is finer (Fig. 2b). Sorting of the material is moderate in the upper water weir bay and moderately good in the lower water weir bay. The grain hydrograph is characterized by symmetry and small variations of soil diameters. The sand at the Transbór weir is characterized by the lowest density. The longitudinal slope of the weir's construction is $6.2 \%$. At the Kocewo weir in the upper weir part the accumulated sand is fatter, in the tail water weir part it is finer (Fig. 2c). Sorting of bed material in the upper and lower weir sections is moderately good, with predominance of particles larger than $D_{50}$. The grain hydrograph does not show any significant kurtosis. This weir is characterized by the smallest longitudinal slope of plate amounting to $2.0 \%$. The ruble occurring on the damming section has the average density when compared to other objects.

Figure 3 presents the relation of ratio percentage content of the fraction in samples taken from the lower weir part, to the corresponding diameters of the soil from the upper weir part. This graph allows to determine which fractions of sediment in the rivers' damming sections are segregated and what is the direction of this process. Diversified process of bed sediment segregation is characteristic for examined weirs. At the Jazgarzew weir the greatest diversity of bed material particles, about 16.0, is observed within the soil diameter range $0.2 \div 1.0 \mathrm{~mm}$. The growth reaching 8.0 was observed at the Transbor weir within the soil diameter range $0.06 \div 0.2 \mathrm{~mm}$. Relatively small increase in the grain content of sediment was noticed within the soil diameter range $0.1 \div 0.3 \mathrm{~mm}$ at the Kocewo weir. In the outer zones of fraction, the sand contained less material in the lower weir part than in the upper.

Figure 4 shows the relation of percentage content of fraction from the upper and lower weir areas. Bisector of the coordinate system represents the theoretical relation, on the assumption of no granulometric differences. The distribution of points obtained for the sediment collected on the examined objects shows the diversity of bed material in the examined weir sections. The greatest diversity of bed material graining appears on the Jazgarzew weir. For diameters larger than $0.21 \mathrm{~mm}$ (equivalent to $15 \%$ of the fraction) higher percentage content 
a) Jazgarzew

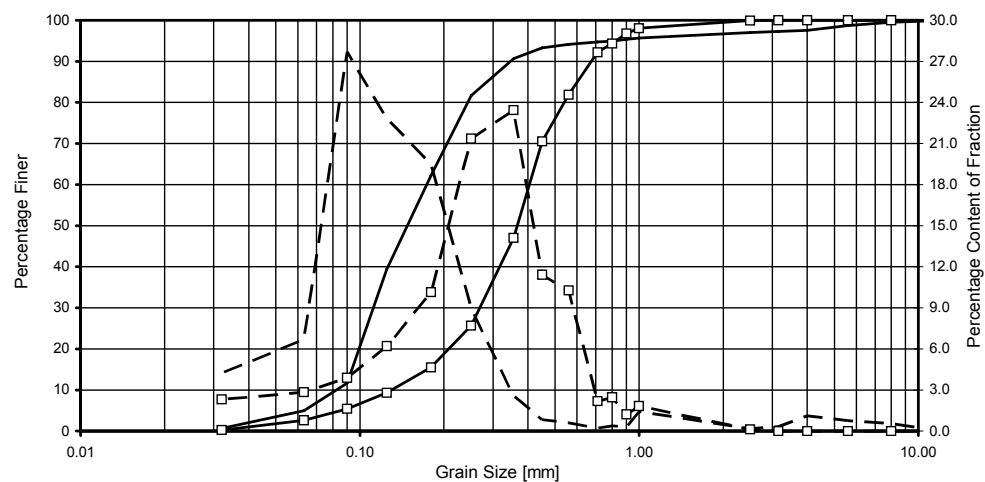

$\longrightarrow$ Cumulative Curve HWL $\rightarrow-$ Cumulative Curve TWL $\quad-\quad-$ Frequency Curve HWL $\rightarrow$ - Frequency Curve TWL

b) Transbór

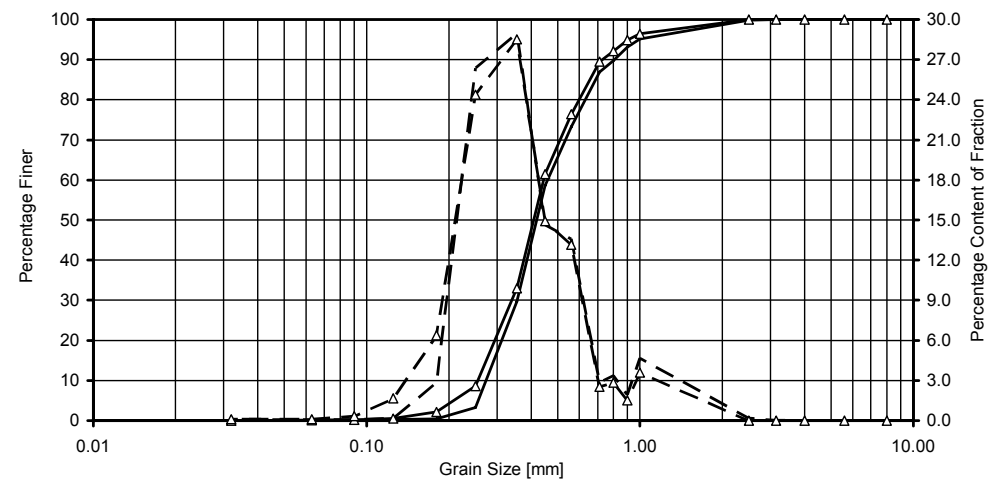

$\longrightarrow$ Cumulative Curve HWL $\longrightarrow$ Cumulative Curve TWL $\quad-$ Frequency Curve HWL $\rightarrow-$ Frequency Curve TWL

c) Kocewo

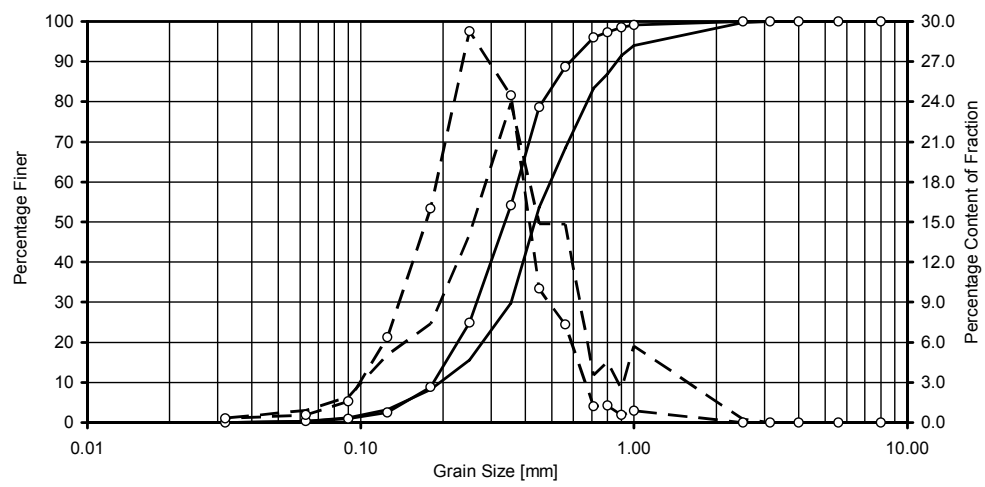

- Cumulative Curve HWL $\multimap$ Cumulative Curve TWL $\quad$-Frequency Curve HWL $\multimap-$ Frequency Curve TWL

FIGURE 2. Frequency and cumulative distribution curves of the bed sediment 


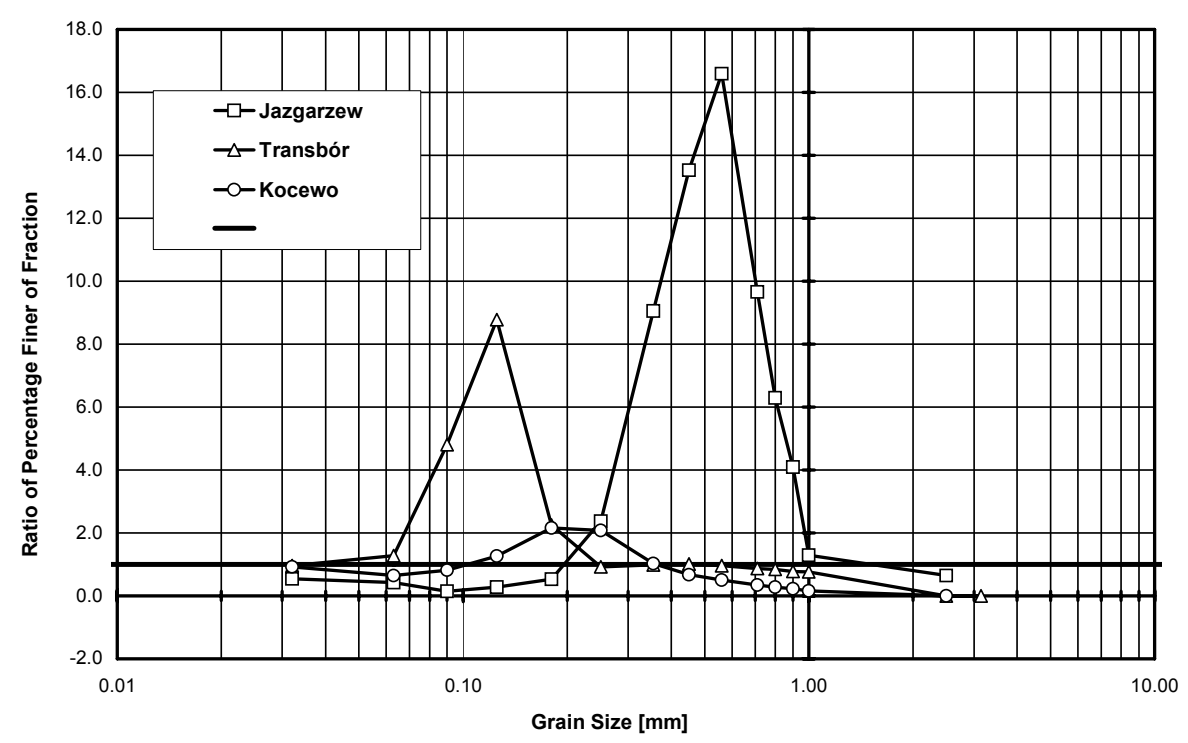

FIGURE 3. Relationship of ratio percentage content of the fraction

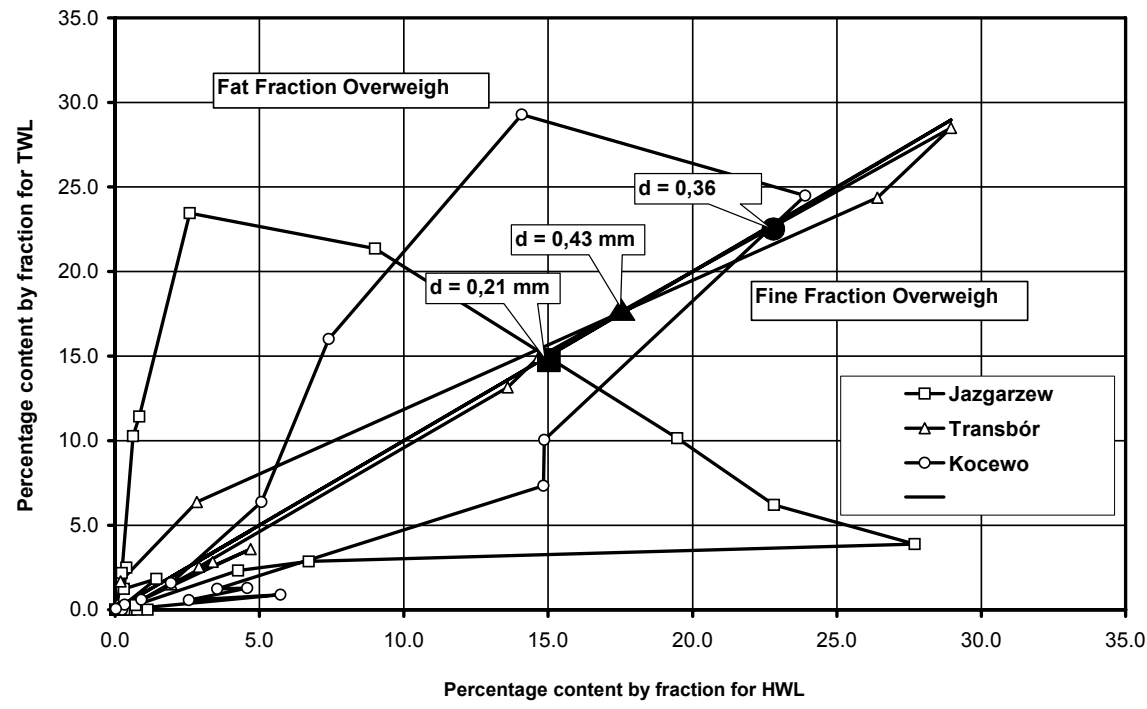

FIGURE 4. Relationship of the percentage content by fraction

of fraction shows the sample from the between the upper and lower weir parts. lower weir part, for the smaller - the The points are located near the line of sample from the upper weir part. At the theoretical homogeneity of soil. For Transbór weir there is only insignificant diameters larger than $0.43 \mathrm{~mm}$ (equivadiversity of the river sediment content lent to $17.5 \%$ of the fraction) dominated 
fatter fractions, for smaller diameters - finer fractions.

Figure 5 shows the relation of percentage content by fraction of smaller for sediment samples collected from the lower weir parts to the respective values for samples collected from the upper weir parts. Figure 5 contains graphic display of variability of sediment graining curves for samples collected from the lower weir part $(0 \mathrm{Y})$ and the upper weir part $(0 \mathrm{X})$ of examined weirs. Bisector of the coordinate system separates two segregation types. Below the border line there is an area of negative segregation type and above - of positive segregation type. The negative type of segregation, expressed by elevating the finer material down the river, is observed on the Jazgarzew weir. Immediately below the weir the fatter material is accumulated. The positive type of segregation characterizes the Kocewo weir, where the upper weir part is an area of fatter material and the lower - of finer particles. The Transbór weir affects the bed material segregation insubstantially. The line the curve for this object is similar to the boundary line, expressing no differences of the bed material between the high water area and the tail water area.

\section{DISCUSSION}

The Jazgarzew weir with the longitudinal slope of $9.6 \%$ has a negative type of segregation. For this weir the high speed of water flow, resulting from the slope of construction, causes the elevation of fine particles from the lower weir part and their transport down the river. Below the weir fatter bed material remains. For the slope of construction at the Transbór weir, amounting to $6.2 \%$, the segregation intensity is low with positive inclinations. At the Kocewo weir the segregation type

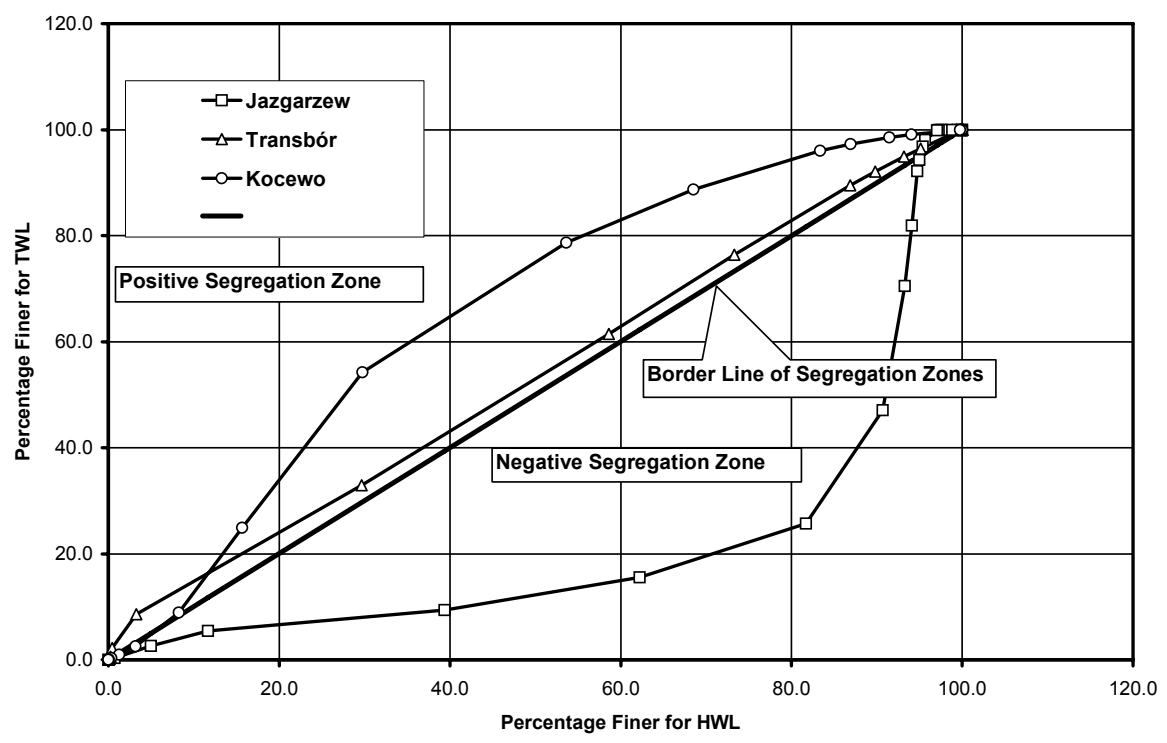

FIGURE 5. Relationship of the percentage content by fraction of smaller 
is positive. With the slope of construction amounting to $2.0 \%$ predominates the transport of fine particles that are accumulated below the weir.

\section{CONCLUSIONS}

The water backing up above the weir causes changes of transport capacity by limiting the free movement of sediment through the water structures. For larger construction and water table slopes there is movement of sediment through the object observed. However, when the flow is sufficiently strong finer particles are elevated down the stream. In the examined weirs the sediment did not amass on the upper inflow section, neither the overflow capacity was modified. The accumulation of sediment was observed in the final section of stilling basin and just below. The granulometric content of accumulated sediment depended on the flow rate, the occurrence of flush flow, the granulation of transported material and the type and condition of surface of rear apron.

The analysis carried out shows that, for the examined weirs, the types of segregation processes are closely related to the longitudinal construction slope. Any relation of forms and range of segregation phenomena with other identified parameters has not been demonstrated. Analyzed curves indicate that the examined weirs affect the segregation processes of bed sediment. This impact is expressed in the variability of the forms, the degree and the intensity of segregation processes.

\section{REFERENCES}

BREUSERS H.N.C., RAUDKIVI A.J., 1991: Scouring. Hydraulc Structures Design Manual.
Taylor and Francis Group. London, New York, pp. 143.

DĄBKOWSKI L., SKIBIŃSKI J., ŻBIKOWSKI A., 1982: Hydrauliczne podstawy projektów wodnomelioracyjnych [Hydraulic bases of water-irrigation projects]. PWRiL. Warsaw. pp. 534 [in Polish].

LAPPO D.D., and others 1988: Gidravličeskie rasčety vodosbrosnyh gidrotehničeskih sooruže nij [Hydraulic calculating of spillways]. Energoatomizdat. Moscow, pp. 624 [in Russian].

ZAWADZKI P., HÄMMERLING M., 2008: Zmiany uziarnienia na dnie poniżej budowli piętrzącej [Changes of bed grain size distribution below hydraulic structure]. Scientific Review Engineering and Environmental Science. Volume XVII 2008. No 2 (40), pp. 146-155 [English summary].

Streszczenie: Segregacja rumowiska na jazach nizinnych. Procesy akumulacjno-erozyjne w pobliżu budowli wodnych rozwijają się w zależności od okresu eksploatacji obiektu, reżimu hydrologicznego oraz morfologii koryta cieku. Zróżnicowanie charakterystyk strumienia na odcinku piętrzenia wpływa na segregację materiału dennego. Znajomość czynników decydujących o zróżnicowaniu granulometrycznym materiału dennego pozwala na właściwsze projektowanie zabezpieczeń dna i skarp. Daje też możliwość oszacowania warunków transportu rumowiska w dół cieku i jego udziału w bilansie transportu materiału dennego w korycie cieku. Obszarami, w których gromadzi się rumowisko na budowlach wodnych są stanowisko górne i dolne, niecka wypadowa oraz inne zagłębienia $\mathrm{w}$ konstrukcji. W artykule poddano analizie skład granulometryczny materiału dennego na wybranych jazach nizinnych. Obiektami badawczymi były jazy położone na rzekach nizinnych. Na odcinkach jazowych występuje tendencja do segregacji rumowiska. W stanowisku górnym gromadzi się rumowisko najgrubsze, przy wylocie najdrobniejsze.

\section{MS. received April 2010}

Authors' address:

Katedra Inżynierii Wodnej i Rekultywacji

Środowiska SGGW

02-787 Warszawa, ul. Nowoursynowska 166

Poland

slawomir_bajkowski@sggw.pl 